\title{
Hyaluronan (HA) content, the ratio of HA fragments and the expression of CD44 in the ovine cervix vary with the stage of the oestrous cycle
}

\author{
K Perry, W Haresign ${ }^{1}$, D C Wathes ${ }^{2}$ and M Khalid \\ Department of Veterinary Clinical Sciences, The Royal Veterinary College, Hawkshead Lane, North Mymms, Hatfield, \\ Hertfordshire, AL9 7TA, UK, ${ }^{1}$ Institute of Biological, Environmental and Rural Sciences, Aberystwyth University, \\ Aberystwyth, SY23 3DA, UK and ${ }^{2}$ Department of Veterinary Basic Sciences, The Royal Veterinary College, \\ Hawkshead Lane, North Mymms, Hatfield, Hertfordshire, AL9 7TA, UK \\ Correspondence should be addressed to M Khalid; Email: mkhalid@rvc.ac.uk
}

\begin{abstract}
The complex anatomy of the ovine cervix limits the success of trans-cervical artificial insemination in sheep. However, there is a degree of natural relaxation of cervix at oestrus that is accompanied by an increase in the water content. As hyaluronan (HA) has a high affinity for water molecules, in this study, we tested the hypothesis that the HA content of the cervix, the proportion of different size fragments of HA and expression of its receptor CD44 vary with the stage of the oestrous cycle. Oestrous was synchronized in 25 Welsh mountain ewes, and their cervices were collected either during luteal phase $(n=8)$ or pre-LH $(n=8)$ or post-LH $(n=9)$ surge stage of the oestrous cycle. The pre-LH surge group had the highest HA content $(2.96 \mathrm{ng} / \mathrm{mg}$ of cervical tissue), which was significantly $(P \leq 0.05)$ higher than that observed for the post-LH surge $(2.04 \mathrm{ng} / \mathrm{mg})$ group. The luteal phase group had a mean HA content intermediate between the pre- and post-LH surge groups, and was significantly different from either. The frequency of cervical samples containing both sizes of HA fragments (small and large) was significantly higher $(\boldsymbol{P} \leq \mathbf{0 . 0 5})$ in the pre-LH surge group compared with the luteal and the post-LH surge groups, whereas that in post-LH surge group was significantly $(P \leq 0.05)$ higher than that in the luteal group. The number of cervical samples that contained only small HA fragments was significantly $(P \leq 0.05)$ higher in the luteal group compared with both the pre- and post-LH surge groups, whereas the number of samples containing only large HA fragments was significantly $(P \leq 0.05)$ higher in the post-LH surge group compared with the luteal or pre-LH surge groups. Overall mean expression of CD44 in the vaginal and mid regions was significantly $(\boldsymbol{P} \leq \mathbf{0 . 0 0 1})$ higher than that in the uterine region, with no difference between the vaginal and mid regions of the cervix. Pattern of CD44 expression depended on the stage of the oestrous cycle. At the luteal stage, CD44 expression did not vary among epithelial, sub-epithelial, circular and longitudinal smooth muscle layers, whereas at the pre- and post-LH surge stages, the expression in the epithelial layer was significantly $(\boldsymbol{P} \leq \mathbf{0 . 0 0 1})$ higher than that in the other three layers. In general, CD44 expression in the transverse smooth muscle layer was significantly $(\boldsymbol{P} \leq \mathbf{0 . 0 5})$ lower than the expression in all the other layers at all the stages of the oestrous cycle. The results indicated that the HA varied with the steroid status. Higher HA values at a time when cervical relaxation is naturally higher may indicate its involvement in remodelling of the cervix at oestrus.
\end{abstract}

Reproduction (2010) 140 133-141

\section{Introduction}

Schemes for genetic improvement of sheep can make a significant economic impact on the UK sheep industry. However, maximum benefit depends on the use of artificial insemination (Al) with frozen-thawed (FT) semen because fresh semen is viable for only $8 \mathrm{~h}$ and sheep farms are geographically widely distributed. Fertility following cervical AI with FT semen is poor and not commercially acceptable. The use of FT semen with laparoscopic intrauterine Al gives acceptable results but the procedure itself is not welfare friendly. A practical solution is trans-cervical intrauterine insemination. However, the cervical lumen in sheep is convoluted, and the passage of an insemination pipette into the uterus is not currently practicable. Lambing rates are considerably increased with an increase in the depth of cervical insemination (Salamon \& Maxwell 1987), but the inseminating pipette can rarely be inserted more than $1 \mathrm{~cm}$ into the sheep cervix (Alvarez et al. 1998). This is mainly due to the second and third cervical rings being frequently out of alignment with the first.

The sheep cervix consists mostly of connective tissue including collagen, elastin and the macromolecular components that make up the extracellular matrix 
(ECM). The ECM of the cervix includes mainly thick collagen fibre bundles running in all directions, and very small amounts of elastin held together by an amorphous matrix principally comprising proteoglycans, glycoproteins, HA and water (Fosang et al. 1990). Since the properties of the connective tissue are dependent upon the type, concentration and interaction of the components that comprise the ECM, the functional properties of the cervix may be dramatically altered by changes in these components of the ECM. It is generally believed that the cervix functions through remodelling of the ECM components such as dissociation of collagen fibres, degradation of proteoglycans and the release of glycosaminoglycans (GAGs; Leppert 1992), specifically during late gestation, parturition and oestrus.

GAGs are essential components of the cervical ECM. They contribute to cell recognition, cellular adhesion and growth regulation (Erlinger 1995). The most common GAG found within the ovine cervix is hyaluronan (HA; Kershaw et al. 2005). It is secreted from the fibroblasts, and is stimulated by a wide variety of agents including hormones, prostaglandins (PG), interleukin 1 and lipopolysaccharides (Tanaka et al. 1994). HA is localized to the stromal ECM (El Maradny et al. 1997), and its biological role in cervical remodelling is hypothesized but not well defined. Because cervical relaxation at oestrus is accompanied by an increase in water content (Tsiligianni et al. 2001) and HA has a high affinity for water molecules (Takemura et al. 2005), a proposed role for HA in cervical remodelling is thought to be in promotion of tissue hydration. The accumulation of HA and water molecules in the interstices between the collagen fibrils may promote dispersion or prevent aggregation of the collagen fibrils, thus weakening the tensile strength of the matrix (El Maradny et al. 1997). As there is a natural degree of relaxation of cervix at oestrus, we hypothesize that the HA content of the cervix varies with the stage of the oestrous cycle and increases at oestrus.

$\mathrm{HA}$ is synthesized by a class of integral membrane proteins called HA synthases (Watanabe \& Yamaguchi 1996), and is degraded by a family of enzymes called hyaluronidases (Obara et al. 2001) resulting in different molecular weight fragments which may exhibit different properties (Kikuchi et al. 1996, Ghosh \& Guidolin 2002, Alaniz et al. 2009). Low-molecular weight HA fragments have been reported to induce cytokines and chemokines that are implicated in inflammation and degradation of ECM (Noble et al. 1996). Moreover, low-molecular weight HA is angiogenic (West et al. 1985), and can induce cytokine (Hiro et al. 1986) and matrix metalloproteinase production (El Maradny et al. 1997) as well as nitric oxide synthesis (McKee et al. 1997), all of which are inducers of cervical ripening. On the other hand, high-molecular weight HA suppresses angiogenesis (Fienberg et al. 1983).
The degree of relaxation of cervix varies with the stage of the oestrous cycle, and is highest at oestrus. Taken together, this may mean that HA fragments of a particular molecular weight may be more active and/or available to carry out their function at oestrus. However, it remains to be determined whether the proportion of different size fragments of HA in the cervix varies with the stage of the oestrous cycle in a manner that parallels the degree of relaxation of the cervix.

The biological actions of HA may be mediated by binding to its cell surface receptor, CD44 (Aruffo et al. 1990), or receptors like RHAMM (Slevin et al. 2007), versican (Ruscheinsky et al. (2008) and HA-binding proteins such as heavy chain subunit of the inter$\alpha$-trypsin inhibitor protein family (ITI; Zhuo et al. 2003). The CD44 family belongs to a larger group of HA-binding proteins, termed the hyaladherins (Toole 1990). CD44 mediates HA-dependent cell adhesion, which has been observed in a number of different cell types, including epithelial cells (Culty et al. 1992), leukocytes and fibroblasts (Underhill 1992). The interaction of HA to the well-characterized receptor, CD44, activates a signalling cascade involving small GTP-binding proteins and MAP kinase signalling pathways (Itano \& Kimata 2002). While the amount of $\mathrm{HA}$ bound at the cell surface is influenced by several factors, e.g. type or isoform of CD44 (Stamenkovic et al. 1991) or the presence of the carbohydrate side chains of CD44 (Lokeshwar \& Bourguignon 1991), it remains to be determined whether CD44 expression in the cervix is regulated by different hormonal milieus during different stages of the oestrous cycle. Thus, our hypothesis in the present study was HA content, the ratio of different sizes of $\mathrm{HA}$ and the expression of its receptor CD44, change in the cervical stroma depending on the stage of the oestrous cycle in sheep.

\section{Results \\ Plasma progesterone and $\mathrm{LH}$ concentrations}

All the ewes exhibited plasma progesterone $\left(\mathrm{P}_{4}\right)$ profiles characteristic with the stage of the oestrous cycle. As expected, higher $\mathrm{P}_{4}$ concentrations $(4.02 \pm 0.32 \mathrm{ng} / \mathrm{ml})$ were observed in the luteal ewes and basal $(0.22$ $\pm 0.02 \mathrm{ng} / \mathrm{ml}$ ) in the pre- and post-LH surge ewes (Scott et al. 2001). The LH profiles showed basal LH concentrations during the luteal and early follicular phase with concentrations increasing $31-34 \mathrm{~h}$ after $\mathrm{PGF}_{2 \alpha}$ injection. The LH surge $(23.2 \pm 4.3 \mathrm{ng} / \mathrm{ml})$ coincided with the GNRH injection and lasted $4-5 \mathrm{~h}$, at these levels it was similar to that reported by (Scott et al. 2001). At the culling time, the ewes in the luteal and pre-LH surge groups had basal/lower LH concentrations $(0.6-1.2 \mathrm{ng} / \mathrm{ml})$, whereas those in the post-LH surge group had been exposed to the $\mathrm{LH}$ surge at least $3 \mathrm{~h}$ before the collection of cervices. 


\section{HA content}

The data on the HA content are reported on the basis of dry weight of the cervix. The HA content of the cervix did not differ among the regions of the cervix. However, there was a significant $(P \leq 0.05)$ difference among different stages of the oestrous cycle. The pre-LH surge group showed the highest HA content $(2.96 \pm 0.39 \mathrm{ng} / \mathrm{mg}$ of cervical tissue), which was significantly $(P \leq 0.05)$ higher than that observed for the post-LH surge group $(2.04 \pm 0.19 \mathrm{ng} / \mathrm{mg})$. The luteal phase group had a mean HA content $(2.28 \pm 0.22 \mathrm{ng} / \mathrm{mg})$ intermediate between the pre- and post-LH surge groups, and was not significantly different from either (Fig. 1).

Changes in tissue hydration were observed in relation to stage of the cycle. The cervical tissue collected from the pre-LH animals had the highest water content, which contained significantly $(P \leq 0.05)$ more $(75.7 \%)$ fluid than the tissue collected from the luteal group. However, the moisture content of the cervix did not differ between the post-LH surge group and the luteal or the pre-LH surge groups.

\section{HA fragment size}

The number of cervical samples containing both small (200-2000 kDa) and large ( $\geq 2000 \mathrm{kDa}) \mathrm{HA}$ fragments was highest $(33 / 75 ; 44 \%)$ followed by those containing only large HA fragments $(27 / 75 ; 33 \%)$ or only small fragments $(15 / 75 ; 20 \%)$. The frequency of cervical samples containing different sizes of HA fragments did not vary among the three regions of the cervix, but was significantly $(P \leq 0.05)$ different among the three stages of the oestrous cycle (Fig. 2). The frequency of samples containing both sizes of HA fragments (small and large) was significantly higher $(P \leq 0.05)$ in the pre-LH surge group compared with the post-LH surge group, which

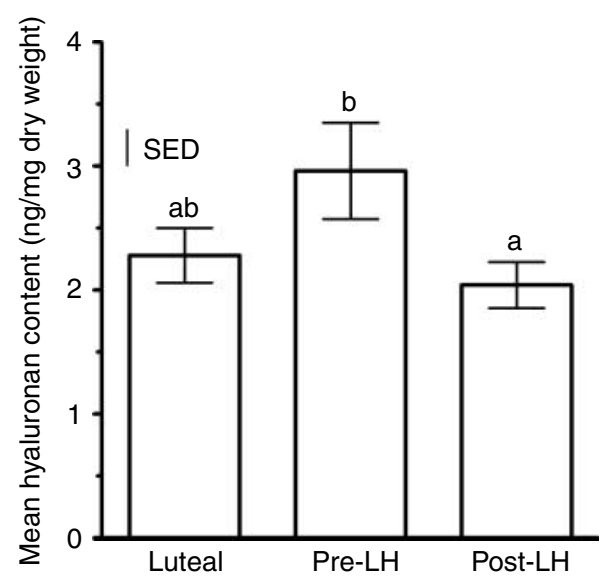

Figure 1 Mean ( \pm S.E.M.) HA content (ng/mg of cervical tissue) of the cervices of sheep at the luteal $(n=8)$, pre-LH $(n=8)$ and post-LH $(n=9)$ surge stages of the oestrous cycle. SED (0.39) indicates the standard error of difference between means. Bars with different letters indicate significant differences (a versus $\mathrm{b} ; P \leq 0.05$ ).
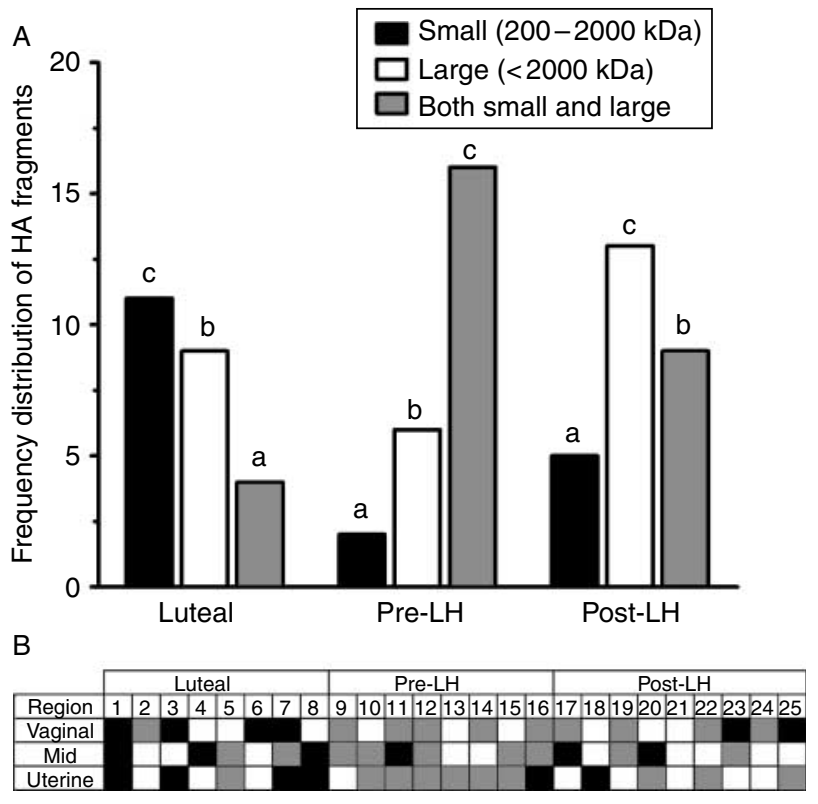

Figure 2 (A) Frequency distribution of small (black bars, 200$2000 \mathrm{kDa}$ ), large (white bars, $\leq 2000 \mathrm{kDa}$ ) and both small and large (grey bars) fragments of hyaluronan in sheep cervix at the luteal $(n=8)$, pre-LH $(n=8)$ and post-LH $(n=9)$ surge stages of the oestrous cycle. Bars with different letters denote significant differences, both within and between different stages of the oestrous cycle (a versus b, b versus $c$, a versus c; all $P \leq 0.05$ ). (B) Frequency distribution of small (black boxes, 200-2000 kDa), large (white boxes, $\leq 2000 \mathrm{kDa}$ ) and both small and large (grey boxes) fragments of hyaluronan in different regions of the cervix and at the luteal $(n=24)$, pre-LH $(n=24)$ and post-LH $(n=27)$ surge stages of the oestrous cycle.

was significantly $(P \leq 0.05)$ higher than that in the luteal group. The number of cervical samples that contained only small HA fragments was significantly $(P \leq 0.05)$ higher in the luteal group compared with both the preand post-LH surge groups, whereas the number of samples containing only large HA fragments was significantly $(P \leq 0.05)$ higher in the post-LH group compared with the luteal or pre-LH surge groups (Fig. 2).

\section{CD44 expression}

CD44 expression in the cervix was significantly $(P \leq 0.001)$ affected by the region and the layer of the cervix as well as by the stage of the oestrous cycle. In the vaginal and mid regions, CD44 expression was significantly $(P \leq 0.001)$ higher than that in the uterine region, whereas no difference was observed between the vaginal and mid regions of the cervix (Fig. 3).

A significant $(P \leq 0.001)$ interaction between the layer and the stage of the oestrous cycle indicated that the pattern of CD44 expression in the cervical layers was not the same for different stages of the oestrous cycle (Fig. 4b). CD44 expression in the transverse smooth muscle layer was significantly $(P \leq 0.05)$ lower than the expression in all the other layers at all the stages of 


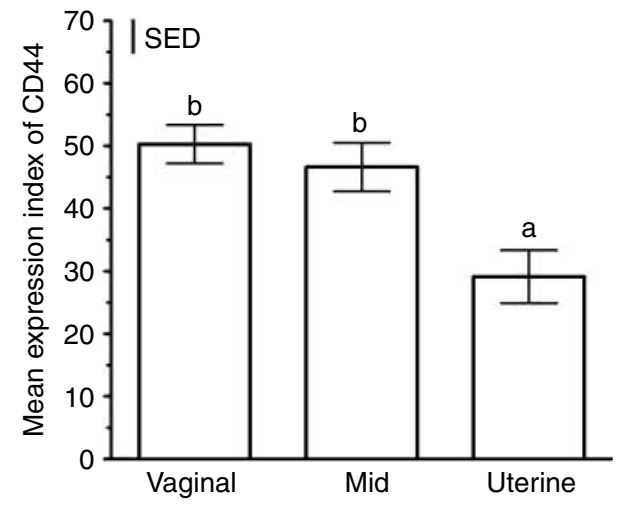

Figure 3 Mean ( \pm s.E.M.) expression of CD44 in the uterine, mid and vaginal regions of the cervix in sheep at the luteal $(n=8)$, pre-LH $(n=8)$ and post-LH $(n=9)$ surge stages of the oestrous cycle. SED (5.0) indicates the standard error of difference between means. Bars with different letters indicate significant differences (a versus $b ; P \leq 0.001$ ).

the oestrous cycle, except in the sub-epithelial layer of the luteal and the post-LH surge stages. At the luteal stage, CD44 expression did not vary among epithelial, subepithelial, circular and longitudinal smooth muscle layers, whereas at the pre-and post-LH surge stages, the expression in the epithelial layer was significantly $(P \leq 0.001)$ higher than that in the other three layers. While there was no difference in the CD44 expression between the subepithelial, circular and longitudinal smooth muscle layers at the post-LH surge stage, at the pre-LH surge stage, the expression in the sub-epithelial layer was significantly $(P \leq 0.001)$ lower than that in the circular and longitudinal smooth muscle layers of the cervix (Fig. 4b).

\section{Discussion}

The patency of the ovine cervix to semen is increased during the oestrus period to facilitate sperm transport and fertilisation (Hawk \& Cooper 1977). However, the mechanism by which this is achieved and the role of $\mathrm{HA}$ in this process have not been thoroughly investigated. This study examined whether the HA, its varying fragments sizes and primary receptor CD44 vary in different regions of the ovine cervix at different stages of the oestrous cycle, which were confirmed by measuring plasma $\mathrm{P}_{4}$ and $\mathrm{LH}$ concentrations. At the culling time, the ewes in the luteal and pre-LH surge groups had basal/ lower LH concentrations that are comparable to the values reported earlier (Scott et al. 2001). The ewes in the post-LH surge group had been exposed to the LH surge at least $8 \mathrm{~h}$ before the cervices were collected. The significantly higher $\mathrm{P}_{4}$ concentrations observed in the luteal ewes and the basal values at the pre- and postLH surge stages were also consistent with the results from earlier studies (Scott et al. 2001).

In our study, we observed that the HA content of the cervix was significantly higher in the pre-LH group compared with the luteal or post-LH surge groups, which may suggest that the cervical HA content varies with the steroid status. The higher HA content in the pre-LH surge group seems to be the result of accumulation during the luteal phase when these ewes were exposed to higher concentrations of $\mathrm{P}_{4}$ or alternatively rising oestrogen concentrations during the pre-LH surge stage might have played a role in this process. Evidence from a number of studies (Anderson et al. 1991, Rajabi et al. 1992, Ruscheinsky et al. 2008) suggest that higher $P_{4}$ concentrations during pregnancy are implicated to increase the cervical HA content in a number of species. However, definite effects of oestrogens on the HA content are difficult to determine from the results of this study, and remain to be investigated. Nevertheless, $\mathrm{HA}$ content is reported to be the highest at term, at a time when $\mathrm{P}_{4}$ effect is withdrawn and there is relatively oestrogen dominance (Turnbull et al. 1974), a situation similar to that what we see in the pre-LH surge stage of the oestrous cycle.

In the present study, the HA content of the cervix was significantly higher at the pre-LH surge stage, which might explain a degree of natural relaxation of the cervix observed at oestrus (Granstrom et al. 1989) that is possibly achieved by loosening and dispersal of collagen fibres by water attracted by HA (Straach et al. 2004). It is noteworthy that in the present study, HA content is reported on the basis of dry weight of cervix and is, therefore, real and does not reflect any changes in the water content.

The results of the present study have shown that the luteal group had more cervical samples containing smaller HA fragments, and the post-LH surge group had more samples containing large HA fragments, whereas the pre-LH group had significantly more samples containing both small and large HA fragments. However, it is not known from the results of this study whether the enzymes resulting in synthesis or degradation are involved in generating and maintaining the observed $\mathrm{HA}$ polymer sizes. Nevertheless, HA polymers of different sizes have a vast array of functions (Kikuchi et al. 1996, Watanabe \& Yamaguchi 1996, Ghosh \& Guidolin 2002, Alaniz et al. 2009). Smaller HA fragments (200$2000 \mathrm{kDa})$ are involved in a variety of normal and pathological processes (Stern et al. 2006); they also come in sizes that overlap in the functions that they perform. Low-molecular weight HA administration has been shown to induce cervical ripening in rabbits (El Maradny et al. 1997), suggesting its role in cervical remodelling. HAase increases during cervical ripening (Obara et al. 2001) because of high concentrations of $P_{4}$ and/or its receptor (Tanyildizi \& Bozkurt 2002), and results in degradation of $\mathrm{HA}$ into smaller fragments. The increase in $\mathrm{P}_{4}$ seen in the luteal phase mirrors that seen during pregnancy, and this may help to explain why the luteal group has the highest frequency of smaller $\mathrm{HA}$ fragments in comparison with the other stages of the oestrous cycle. 
(a)
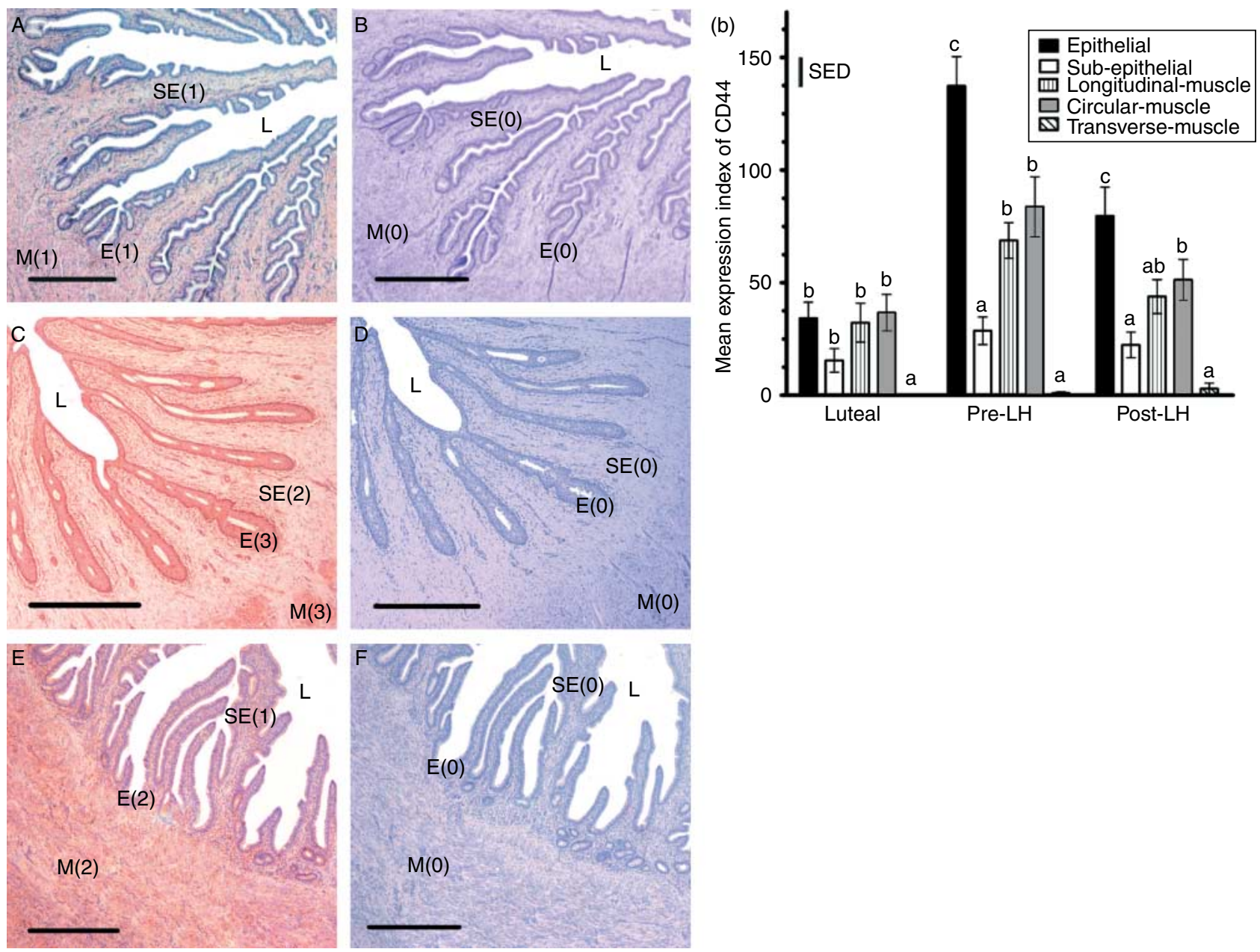

Figure 4 (a) Immunohistochemical localisation (A-F) of CD44 receptor, shown as red staining (Nova red), in the vaginal region of the cervix of a sheep at the luteal (A), pre-LH (C) and the post-LH (E) surge stage of the oestrous cycle (L, lumen; E, epithelial; SE, sub-epithelial; M, muscle). Expression scores range from 0 to 3 , and are shown in brackets. No staining (score $=0$ ) was observed in the negative control sections ( $\mathrm{B}, \mathrm{D}$ and $\mathrm{F}$ ). Bar $=25 \mu \mathrm{m}$. (b) Mean ( \pm s.E.M.) expression of CD44 in the epithelial, sub-epithelial, longitudinal-muscle, circular-muscle and transverse-muscle layer of the cervix in sheep at the luteal $(n=8)$, pre- $\mathrm{LH}(n=8)$ and post-LH $(n=9)$ surge stages of the oestrous cycle. SED (11.2) indicates the standard error of difference between means to compare the mean values for CD44 expression between different cell layers both within and between different stages of the oestrous cycle. Bars with different letters indicate significant differences (a versus $b$ and $b$ versus $c$; $P \leq 0.05$, a versus c; $P \leq 0.001)$.

In this study, the pre-LH surge group had significantly more samples that contained both small and large HA fragments. However, from the HPLC results, it is difficult to establish the ratio of $\mathrm{HA}$ fragments within the samples. While the presence of large HA fragments in the cervical samples may be explained on the basis of a decreased effect of HAase because of lower concentrations of $\mathrm{P}_{4}$ or its receptor (Obara et al. 2001, Uchiyama et al. 2004), the existence of smaller HA fragments within the same samples may be the result of an increased production of HAS1 and HAS3 (Itano \& Kimata 2002), which may be stimulated by exposure to either the increased concentrations of PGs at luteolysis (Stuhlmeier 2007) or oestrogens (Uzuka et al. 1981) and/or LH (Schoenfelder \& Einspanier 2003). However, to ascertain the definite effects of these hormones on HA synthase(s), it requires further studies.

The major HA receptor is CD44 that mediates HA-dependent cell adhesion in a number of different cell types, including epithelial cells (Culty et al. 1992) leukocytes and fibroblasts (Underhill 1992). Previously reported biochemical and cell biological properties of CD44 are consistent with its role as a cell surface glycoprotein (Brown et al. 1991). It is hypothesized that CD44 forms a direct association between $\mathrm{HA}$ and the cytoskeleton. However, the mechanism by which CD44 achieves this, including the signalling cascades that it regulates, is complex (Turley et al. 2002); nevertheless, the particular downstream signalling pathways lead to an onset of HA-dependent functions in various types of 
tissues (Turley et al. 2002). Although in this study, we have focused only on CD44 that may alter or modulate the function of HA in the cervix; however, there are also other receptors like RHAMM (Slevin et al. 2007) and HA-binding proteins such as heavy chain subunit of the ITI |al) or versican (Ruscheinsky et al. (2008), which may play a role in influencing HA functions in the cervix.

In the present study, we observed a significantly higher CD44 expression in the luminal epithelium of the cervix, a finding that is consistent with those of Fosang et al. (1984), El Maradny et al. (1997) and Ruscheinsky et al. (2008) who also reported the expression of CD44 being mainly around the basal layer of cervical epithelium. However, in addition to luminal epithelium, we also observed the expression in the sub-epithelial stroma layer, whereas studies such as those by Ruscheinsky et al. (2008) did not report any expression in this region. The differences between our results and those of Ruscheinsky et al. (2008) may be explained on the basis of either different species (ewes versus mice) and/or physiological status of the animals (non-pregnant versus pregnant). A higher expression of CD44 in the epithelium suggests a possible interaction between $\mathrm{HA}$ and its receptor CD44, and an increase in HA may upregulate CD44 function. This supports the fact that higher HA content and expression of CD44 were both observed during the same (pre-LH surge) stage of the oestrous cycle. The higher HA content during the pre-LH surge stage may be attributable to both luminal epithelial cells and fibroblasts, thus supporting the evidence that HA synthases are expressed in luminal epithelial cells of the mouse and human cervix (Straach et al. 2004), and is also consistent with unpublished data from our laboratory that HA synthases are expressed in both epithelium and sub-epithelial stroma. Therefore, the increased expression of the CD44 in the epithelium, as observed in the present study, is to ensure its availability to bind to its ligand. Significantly more mucus produced and/or accumulated naturally in the vaginal region of the ewe with increasing amounts towards oestrus (Rexroad \& Barb 1977) explains the difference seen between regions of the cervix and stages of the oestrous cycle.

At all the stages of the oestrous cycle, the vaginal region of the cervix showed the highest CD44 expression in comparison with the mid or uterine regions. As significantly more mucus is produced and/or accumulated naturally in the vaginal region of the ewe (Rexroad \& Barb 1977), higher CD44 in the vaginal region might be explained on the basis of the hypothesis that the HA contained in the mucus upregulates CD44 production and function. A general increase in mucus within the cervix close to oestrus (Rexroad \& Barb 1977) may explain why the pre-LH group had high CD44 expression in both the vaginal and mid regions of the cervix. A build-up of mucus at the vaginal end may force it backward to the mid-cervical region. The mucus containing high levels of HA (Obara et al. 2001) may then upregulate CD44 expression.

It is worth noting that at present, there is very little information available about the role of $\mathrm{HA}$ in nonpregnant cervix. Exposure of the cervix to $\mathrm{P}_{4}$ during the luteal phase of the oestrous cycle is much shorter compared with that during pregnancy. Results of the present study show that HA content of the cervix varies during different stages of the cycle most probably due to different hormonal milieus. These hormones, particularly the steroids, seem to play the same role as they do during pregnancy and/or at the onset of labour but to a lesser extent, probably reflecting the length of exposure particularly to $\mathrm{P}_{4}$. However, the exact role of steroids and/or gonadotrophins in the function and/or regulation of $\mathrm{HA}$ in the ovine cervix still remain a subject for further investigation.

In conclusion, the results of the present study have shown that HA, fragment size and concentration vary considerably during the oestrous cycle. Higher HA values at a time when cervical relaxation is naturally higher may indicate its involvement in remodelling of the cervix at oestrus. It is therefore possible that HA can be utilized to assist in trans-cervical $\mathrm{Al}$, it is commercially available (Lifecore Biomedical, Chaska, MN, USA) as high- or low-molecular weight powder and can be reconstituted to form a viscous solution for deposition in to the cervix of sheep via an inseminating pipette. We suggest that intra-cervical application of HA may promote remodelling of the cervix at oestrus to facilitate trans-cervical Al in sheep. As a matter of fact, lowmolecular weight HA fragments have been reported to induce cytokines and chemokines that are implicated in inflammation and degradation of ECM (Noble et al. 1996). Moreover, low-molecular weight HA is angiogenic (West et al. 1985), and can induce cytokine production (Hiro et al. 1986), matrix metalloproteinase production (El Maradny et al. 1997) and nitric oxide synthesis (McKee et al. 1997), all of which are inducers of cervical ripening. Furthermore, it has been reported that the application of low-molecular weight HA to the cervix of rabbits actually starts cervical ripening (El Maradny et al. 1997).

\section{Materials and Methods}

\section{Animals and tissues}

The study was performed on 25 Welsh mountain ewes under Home Office authorisation in compliance with the Animal (Scientific Procedures) Act, 1986. The ewes were housed indoors on straw, and fed hay and a commercial concentrate diet with water always available.

Ewes were synchronized to a common day of the oestrous cycle by intravaginal Chronogest sponges (Intervet UK Ltd, Cambridge, UK) inserted for 12 days and $200 \mathrm{IU}$ of pregnant mares serum gonadotrophin (Intervet UK Ltd, Buckinghamshire, UK) given i.m. at the time of sponge removal. All ewes 
were in oestrus within $48 \mathrm{~h}$ of sponge withdrawal, which was termed day 0 of the oestrous cycle. On day 8 of the synchronized cycle (luteal phase), the reproductive tracts of eight animals were collected following death by captive bolt and exsanguination. On day 11, the remaining animals were administered i.m. with $125 \mu \mathrm{g}$ of cloprostenol PGF ${ }_{2 \alpha}$ analogue, Estrumate; Schering-Plough Animal Health, Welwyn Garden City, UK), and at $36 \mathrm{~h}$ after the PGF injection, the tracts were collected prior to the LH surge $(n=8)$. At the same time, the remaining animals were administered $300 \mu \mathrm{g}$ of $\mathrm{GNRH}$ (Sigma-Aldrich) to synchronize the LH surge. The tracts were collected $8 \mathrm{~h}$ post-GNRH following the LH surge $(n=9)$. Jugular venous blood samples were taken for the duration of the study (every $48 \mathrm{~h}$ starting on day 0 of the synchronized oestrous cycle until $\mathrm{PGF}_{2 \alpha}$ injection, then every $2 \mathrm{~h}$ thereafter) placed in heparinized tubes and centrifuged at $1700 \mathrm{~g}$ for $10 \mathrm{~min}$ at $4{ }^{\circ} \mathrm{C}$. Plasma was separated and stored at $-20^{\circ} \mathrm{C}$ until analysed for LH and $\mathrm{P}_{4}$.

The cervix was cleared of all unwanted tissues, the anterior vagina was removed and the cervix was separated from the uterus with a transverse cut using a sterile scalpel. The cervix was divided transversely into six equal sections, alternate sections comprising the uterine region, mid region and vaginal region were fixed in neutral buffered formalin $30 \%(\mathrm{BDH}$, Poole, UK), and the other three sections were frozen on dry ice and stored at $-80^{\circ} \mathrm{C}$. Fixed cervices were wax embedded, sectioned at $7 \mu \mathrm{m}$ and mounted onto Superfrost Plus slides (BDH).

\section{Hormone assays}

Plasma $\mathrm{P}_{4}$ concentrations were determined following an extraction procedure, using a charcoal-dextran-coated RIA as described previously (Robinson et al. 2002). The limit of the sensitivity of the assay was $0.09 \mathrm{ng} / \mathrm{ml}$, and the inter- and intraassay coefficients of variation were 2.2 and $2.0 \%$ respectively. $\mathrm{LH}$ concentrations in the plasma were determined by ELISA using the commercially available kit (LH DETECT, CTK Biotech, Inc., San Diego, CA, USA) that detects the LH surge or whether $\mathrm{LH}$ concentrations are basal in the samples.

\section{Measurement of $\mathrm{HA}$ content}

Frozen cervical tissues at the uterine, mid and vaginal region were digested in $0.1 \mathrm{M}$ sodium acetate buffer, $\mathrm{pH}$ 5.8, containing $0.25 \mathrm{mg} / \mathrm{ml}$ papain (Roche Applied Science), $5 \mathrm{mM}$ EDTA and $5 \mathrm{mM}$ L-cysteine hydrochloride anhydrous at $60{ }^{\circ} \mathrm{C}$ for $16-18 \mathrm{~h}$ as described previously (Pitsillides et al. 1994). HA concentration in the digested tissue supernatant was assayed in duplicate by ELISA based on a method by Fosang et al. (1990). Briefly, Dynex 96-well plates (Dynex Technologies, West Sussex, UK) were coated overnight at $37{ }^{\circ} \mathrm{C}$ with $100 \mu$ of human umbilical cord HA (Sigma-Aldrich) diluted in $20 \mathrm{mM}$ sodium carbonate buffer, $\mathrm{pH}$ 9.6, to a final concentration of $25 \mu \mathrm{g} / \mathrm{ml}$. Then, $50 \mu \mathrm{l}$ of standard or diluted sample were added to the wells with $50 \mu \mathrm{l}$ of $0.33 \mu \mathrm{g} / \mathrm{ml}$ biotinylated hyaluronic acid-binding protein (Seikagaku America, Falmouth, MA, USA) and incubated overnight at room temperature. Next, $100 \mu \mathrm{l}$ of streptavidin-biotinylated HRP complex (Amersham Biosciences UK Ltd) diluted to 1:1000 in PBS-Tween were incubated for $30 \mathrm{~min}$ at $37^{\circ} \mathrm{C}$ followed by $100 \mu \mathrm{l}$ of 2,2-azino-bis-(3-ethylbenzthiazoline-6-sulphonic acid) diammonium salt (ABTS) substrate at $37^{\circ} \mathrm{C}$ for $20 \mathrm{~min}$. The optical density of the wells was read at $\mathrm{OD}_{405}$, and the concentration of $\mathrm{HA}$ within the samples was determined against the optical density of the known standards. The concentration of cervical HA was expressed as $\mu \mathrm{g}$ of $\mathrm{HA} / \mathrm{mg}$ of cervix (dry weight). Dry weight was determined using $200 \mathrm{mg}$ of thawed tissue, which was put in an oven $\left(37^{\circ} \mathrm{C}\right)$ overnight to eliminate any moisture. The tissue was weighed and compared to the original (wet) weight. This value was used as a correction factor in the ELISA calculations. The limit of sensitivity of the HA ELISA was $1.6 \mathrm{ng} /$ well of HA. The interand intra-coefficient of variations were 2.40 and $2.8 \%$ respectively.

\section{Determination of $\mathrm{HA}$ fragment size}

HPLC was used to determine the HA fragment size in uterine, mid and vaginal regions of the cervix from each animal. Cervical samples were digested overnight at $55^{\circ} \mathrm{C}$ in lysis buffer that comprised $0.25 \mathrm{mg} / \mathrm{ml}$ papain (Roche Applied Science) in a $0.1 \mathrm{M}$ sodium acetate buffer ( $\mathrm{pH}$ 5.8) containing $5 \mathrm{mM}$ EDTA (Sigma-Aldrich) and $5 \mathrm{mM}$ L-cysteine hydrochloride anhydrous (Sigma-Aldrich). Previous studies have shown that HA content is not affected by this treatment (Pitsillides et al. 1994). The digested samples were analysed by size exclusion HPLC using a Waters 2695 separation module with a Tosohaas TSK gel G6000 $\mathrm{PW}_{\mathrm{XL}}$ (pore size $13 \mu \mathrm{l}$ ), to separate sample components, and a Waters 2487 dual absorbance detector set at $206 \mathrm{~nm}$ wave length, to measure magnitude and retention time of sample HA. The injected volume was $100 \mu \mathrm{l}$, the column flow was $1 \mathrm{ml} / \mathrm{min}$ Ringer's solution and the column temperature was $30^{\circ} \mathrm{C}$. A calibration curve for HA concentration was constructed for each batch of samples by running standards of known concentrations of rooster comb sodium hyaluronate (Sigma) in Ringer solution $(0.0016,0.003,0.006,0.0125,0.025,0.05,0.1$ and $0.2 \mathrm{mg} / \mathrm{ml})$. The HA standards were run at the beginning and end of each HPLC session, to provide a calibration curve, which was highly linear over the range $0.025-0.400 \mathrm{mg} / \mathrm{ml}$. The molecular weights of the standards were determined by laser light scattering. Curve relating retention time to $\mathrm{HA}$ molecular weights have been published previously (Coleman et al. 1997). The semi-logarithmic relationship was approximately linear from $0.21 \times 10^{6}$ to $3.9 \times 10^{6} \mathrm{kDa}$ but the column did not appear to separate molecules larger than this. Retention times were essentially insensitive to $\mathrm{pH}$ outside the range 7.0-7.4.

\section{Immunohistochemistry}

The expression for CD44 was determined by immunohistochemistry (IHC) on wax-embedded cervix sections. The procedure for immunohistochemical localisation for CD44 was the same as previously described by Ponglowhapan et al. (2008) using a Vectastain Elite ABC Kit (Vector Laboratories, Burlingame, CA, USA). A mouse monoclonal anti-ovine CD44 antibody (MCA2219 AbD Serotec, Oxford, UK) was used as 
primary antibody. Three sections per region of the cervix from each animal were examined for both positive antibody staining and negative controls. Negative controls were treated in the same way except that the primary antibody was substituted with normal mouse IgG (sc-2025 Santa Cruz Biotechnology, Inc., Heidelberg, Germany). The observed lack of staining in negative controls indicated high antigen specificity (Fig. 4a).

\section{Quantification of IHC staining}

Examples of positive and negative staining for CD44 are shown in Fig. 4a. The pattern and intensity of protein staining were determined semi-quantitatively using a histochemical score (HSCORE) that has been widely reported in a number of studies (Vermeirsch et al. 1999, Ponglowhapan et al. 2007, 2008, Plante et al. 2009). In this study, all the assessments were carried out blind by one experienced assessor using HSCORE, incorporating both the distribution and the intensity of specific staining as described previously (Ponglowhapan et al. 2008). For each animal, scoring was carried out separately on the five tissue layers (i.e. epithelium, sub-epithelial stroma, longitudinal muscle, circular muscle and transverse smooth muscle) for each of three regions of the cervix. Serosa was only present in some cervices as it was lost during the fixation and embedding procedures and is, therefore, not included in the results. Briefly, the proportion of positively stained cells in five layers in each of three regions of the cervix was defined as the percentage area of the cell layer to the nearest $5 \%$ that had specific staining. The intensity of staining was graded as $0,1,2$ or 3: an intensity score of 0 (Fig. 4a; B, D and F) indicated that there was no expression; 1 (Fig. 4a; A epithelial, sub-epithelial and muscle) light pink to pink, indicated weak staining; 2 (Fig. 4a; E epithelial and muscle) pink, indicated moderate staining; and 3 (Fig. 4a; epithelial and muscle) represented strong staining with a definite pink or red. Expression index was calculated for each sample by multiplying the percentage of positively stained cells with intensity of staining.

\section{Statistical analysis}

The data on HA content and CD44 were compared by factorial ANOVA using GenStat 9th edition (Version 9.1.0.147, Lawes Agricultural Trust, VSN International Ltd, Oxford, UK), among i) three regions of the cervix and ii) three stages of the oestrous cycle, whereas data on CD44 expression were also compared for the additional factor of cervical layers.

HPLC analysis showed three different types of cervical samples containing either i) small (eluted after $8 \mathrm{~min}$ ); ii) large (retention time between 6.3 and $6.7 \mathrm{~min}$ ) or iii) both small and large (showing two peaks one between 6.3 and $6.7 \mathrm{~min}$ and other after $8 \mathrm{~min}$ ) HA fragments. The frequency distribution of different sizes of HA fragments was compared among the three stages of the oestrous cycle and three cervical regions using $\chi^{2}$ analysis.

\section{Declaration of interest}

The authors declare that there is no conflict of interest that could be perceived as prejudicing the impartiality of the research reported.

\section{Funding}

We would like to thank Innovis Ltd and the BBSRC for their support and funding for this project.

\section{References}

Alaniz L, Rizzo M, Malvicini M, Jaunarena J, Avella D, Atorrasagasti C, Aquino J, Garcia M, Marta P, Silva M et al. 2009 Low molecular weight hyaluronan inhibits colorectal carcinoma growth by decreasing tumour cell proliferation and stimulating immune response. Cancer Letters 278 9-16.

Alvarez M, Anel L, Anel E, Boixo JC, Paz P, Chamorro C, Pena FJ, Dominguez JC \& Celorrio I 1998 Relation between the depth of cervical insemination and prolificacy in sheep. Proceedings of the 50th ICAR: Gametes. Development and Function. Milan, Italy. Abstract 504.

Anderson J, Raynes J, Fitzpatrick R \& Dobson H 1991 Increased hyaluronate synthesis and changes in glycosaminoglycan ratios and molecular weight of proteoglycan: synthesised by cultured cervical tissue from ewes at various stages of pregnancy. Biochimica et Biophysica Acta 1075 187-190.

Aruffo A, Stamenkovic I, Melnick M, Underhill C \& Seed B 1990 CD44 is the principal call surface receptor for hyaluronate. Cell 61 1303-1313.

Brown T, Bouchard T, St John T, Wagner E \& Carter WG 1991 Human keratinocytes express a new CD44 core protein $(\mathrm{CD} 44 \mathrm{E})$ as a heparinsulfate intrinsic membrane proteoglycan with additional exons. Journal of Cell Biology 113 207-221.

Coleman PJ, Scott D, Ray J, Mason RM \& Levick JR 1997 Hyaluronan secretion into the synovial cavity of rabbit knees and comparison with albumin turnover. Journal of Physiology 503 645-656.

Culty M, Nguyen HA \& Underhill CB 1992 The hyaluronan receptor (CD44) participates in the uptake and degradation of hyaluronan. Journal of Cell Biology 116 1055-1062.

El Maradny E, Kanayama N, Kobayashi H, Hossain B, Khatun S, Liping S, Kobayashi T \& Terao T 1997 The role of hyaluronic acid as a mediator and regulator of cervical ripening. Human Reproduction 12 1080-1088.

Erlinger R 1995 Glycosaminoglycans in porcine lung: an ultrastructural study using cupromeronic blue. Cell Tissue Research 281 473-483.

Feinberg RN \& Beebe DC 1983 Hyaluronate in vasculogenesis. Science 220 $1177-1179$.

Fosang AJ, Handley CJ, Santer V, Lowther DA \& Thorbun GD 1984 Pregnancy-related changes in the connective tissue of the ovine cervix. Biology of Reproduction 30 1223-1235.

Fosang AJ, Hey NJ, Carney SL \& Hardingham TE 1990 An ELISA plate based assay for hyaluronan using biotinylated proteoglycan $\mathrm{G}_{1}$ domain (HAbinding region). Matrix 10 306-313.

Ghosh P \& Guidolin D 2002 Potential mechanism of action of intra-articular hyaluronan therapy in osteoarthritis: are the effects molecular weight dependant? Seminars in Arthritis and Rheumatism 32 10-37.

Granstrom L, Elkman G, Ulmsten U \& Malmstrom A 1989 Changes in the connective tissue of the corpus and cervix uteri during ripening and labour in term pregnancy. British Journal of Obstetrics and Gynecology 96 1198-1202.

Hawk HW \& Cooper BS 1977 Sperm transport in to the cervix of the ewe after regulation of estrus with prostaglandin or progestogen. Journal of Animal Science $\mathbf{4 4}$ 638-644.

Hiro D, Ito A \& Mori Y 1986 Hyaluronic acid is an endogenous inducer in interleukin-1 production by human monocytes and rabbit macrophages. Biochemical and Biophysical Research Communications 140 715-722.

Itano N \& Kimata K 2002 Mammalian hyaluronan synthases. IUBMB Life 54 195-199.

Kershaw CM, Khalid M, McGowan MR, Ingram K, Leethongdee S, Wax G \& Scaramuzzi R 2005 The anatomy of the sheep cervix and its influence on the transcervical passage of an inseminating pipette into the uterine lumen. Theriogenology 64 1225-1235.

Kikuchi T, Yamada H \& Shimmei M 1996 Effect of high molecular weight hyaluronan on cartilage degeneration in rabbit model of osteoarthritis. Osteoarthritis and Cartilage 4 99-110.

Leppert PC 1992 Cervical softening, effacement, and dilatation: a complex biochemical cascade. Journal of Maternal-Fetal Medicine 1 213-233. 
Lokeshwar VB \& Bourguignon LY 1991 Post-translational protein modification and expression of ankyrin-binding site(s) in GP85 (Pgp-1/ CD44) and its biosynthetic precursors during T-lymphoma membrane biosynthesis. Journal of Biological Chemistry 266 17983-17989.

McKee CM, Lowenstein CJ, Horton MR, Wu J, Bao C \& Chin BY 1997 Hyaluronan fragments induce nitric-oxide synthesis in murine macrophages through a nuclear factor kappaB-dependent mechanism. Journal of Biological Chemistry 272 8013-8018.

Noble P, Mckee W, Cowman CM \& Shin M 1996 Hyaulronan fragments activate an NF-kappa B/I-kappa B alpha auto regulatory loop in murine macrophages. Journal of Experimental Medicine 183 2373-2378.

Obara M, Hirano H, Ogawa M, Tsubaki H, Hosoya N, Yoshida $Y$, Miyauchi S \& Tanaka T 2001 Changes in molecular weight of hyaluronan and hyaluronidase activity in uterine cervical mucus in cervical ripening. Acta Obstetricia et Gynecologica Scandinavica 80 492-496.

Pitsillides AA, Worrall JG, Wilkinson LS, Bayliss MT \& Edwards JC 1994 Hyaluronan concentration in non-inflamed and rheumatoid synovium. British Journal of Rheumatology 33 5-10.

Plante BJ, Kannan A, Bagchi MK, Yuan L \& Young SL 2009 Cyclic regulation of transcription factor C/EBP beta in human endometrium. Reproductive Biology and Endocrinology 7 15-22.

Ponglowhapan S, Church DB, Scaramuzzi RJ \& Khalid M 2007 Luteinizing hormone and follicle-stimulating hormone receptors and their transcribed genes (mRNA) are present in the lower urinary tract of intact male and female dogs. Theriogenology 67 353-366.

Ponglowhapan S, Church DB \& Khalid M 2008 Differences in the expression of luteinizing hormone and follicle-stimulating hormone receptors in the lower urinary tract between intact and gonadectomised male and female dogs. Domestic Animal Endocrinology 34 339-351.

Rajabi M, Quillen EW, Nuwayhid BS, Brandt R \& Poole AT 1992 Circulating hyaluronic acid in nonpregnant, pregnant, and postpartum guinea pigs: elevated levels observed in parturition. American Journal of Obstetrics and Gynecology 166 242-246.

Rexroad CE \& Barb CR 1977 Cervical mucus in estrous ewes after treatment with estrogen, progestogens and interuterine devices. Journal of Animal Science 44 102-105.

Robinson RS, Pushpakumara PG, Cheng Z, Peters AR, Abayasekara DR \& Wathes DC 2002 Effects of dietary polyunsaturated fatty acids on ovarian and uterine function in lactating dairy cows. Reproduction 124 119-131.

Ruscheinsky M, De la Motte C \& Mahendroo M 2008 Hyaluronan and its binding proteins during cervical ripening and parturition: dynamic changes in size, distribution and temporal sequence. Matrix Biology 27 487-497.

Salamon S \& Maxwell WMC 1987 Salamon's Artificial Insemination of Sheep and Goats, p. 194. Sydney: Butterworths Publishing.

Schoenfelder M \& Einspanier R 2003 Expression of HAS and corresponding hyaluronan receptors is differential. Biology of Reproduction $\mathbf{6 9}$ 269-277.

Scott CJ, Pereira AM, Tilbrook AJ, Rawson AJ \& Clarke IJ 2001 Changes in preoptic and hypothalamic levels of progesterone receptor mRNA across the oestrous cycle of the ewe. Journal of Neuroendocrinology 13 401-406.

Slevin M, Krupinski J, Gaffney J, Maton S, West D, Delisser H, Savani R \& Kumar S 2007 Hyaluornan mediated angiogenesis in vascular disease: uncovering RHAMM and CD44 receptor signalling pathways. Matrix Biology 26 58-68.
Stamenkovic I, Aruffo A, Amito M \& Saeed B 1991 The hematopoietic and epithelial forms of CD44 are distinct polypeptides with different adhesion potentials for hyaluronate-bearing cells. EMBO Journal $\mathbf{1 0}$ 343-348.

Stern R, Asari A \& Sugahara K 2006 Hyaluronan fragments: an informationrich system. European Journal of Cell Biology 85 699-715.

Straach K, Shelton M, Richardson JA, Hascall VC \& Mahendroo S 2004 Regulation of hyaluronan expression during cervical ripening. Glycobiology 15 55-65.

Stuhlmeier KM 2007 Prostaglandin $E_{2}$ : a potent activator of HAS1 in type-B-synoviocytes. Biochimica et Biophysica Acta 1170 121-129.

Takemura M, Itoh H, Sagawa N, Yura S, Korita D, Kakui K, Kawamure M, Hirota N, Maeda H \& Fujii S 2005 Cyclic mechanical stretch augments hyaluronan production in cultured human uterine cervical fibroblast cells. Molecular Human Reproduction 11 659-665.

Tanaka K, Nakamura T \& Ikeya H 1994 Hyaluronate depolymerization activity induced by progesterone in cultured fibroblasts derived from human uterine cervix. FEBS Letters 347 95-98.

Tanyildizi S \& Bozkurt T 2002 Effects of progesterone and testosterone of the hyaluronidase activities and sperm characteristics in sheep. Turkish Journal of Veterinary and Animal Science 26 1137-1143.

Toole BP 1990 Hyaluronan and its binding proteins, the hyaladherins. Current Opinion in Cell Biology 2 839-844.

Tsiligianni TT, Karagiannidis A, Brikas P \& Saratsis PH 2001 Chemical properties of bovine cervical mucus during normal estrus and estrus induced by progesterone and/or PGF $2 \alpha$. Theriogenology 1 41-50.

Turley EA, Noble PW \& Bourguignon LYW 2002 Signaling properties of hyaluronan receptors. Journal of Biological Chemistry 277 4589-4592.

Turnbull AC, Patten PT, Flint AP, Keirse MJ, Jeremy JY \& Anderson AB 1974 Significant fall in progesterone and rise in oestradiol levels in human peripheral plasma before onset of labour. Lancet 1(7848) 101-103.

Uchiyama T, Matsumoto T, Suzuki T, Ishida M, Obara T \& Kanayama T 2004 Endogenous hyaluronan: a cytokine-like factor present in rabbit uterine cervix during pregnancy. Biological \& Pharmaceutical Bulletin 27 1907-1912.

Underhill C 1992 CD44: the hyaluronan receptor. Journal of Cell Science $103293-298$

Uzuka M, Nakajima K, Ohta S \& Mori Y 1981 Induction of hyaluronic acid synthetase by estrogen in the mouse skin. Biochimica et Biophysica Acta 673 387-393

Vermeirsch H, Simoens P, Lauwers H \& Coryn M 1999 Immunohistochemical detection of estrogen receptors in the canine uterus and their relation to sex steroid hormone levels. Theriogenology 51 729-743.

Watanabe K \& Yamaguchi Y 1996 Molecular identification of a putative human hyaluronan synthase. Journal of Biological Chemistry 271 22945-22948.

West DC, Hampson IN, Arnold F \& Kumar S 1985 Angiogenesis induced by degradation products of hyaluronic acid. Science 228 1324-1326.

Zhuo B, McGary Carl T, Weigel JA, Saxena A \& Weigel PH 2003 Purification and molecular identification of the human hyaluornan receptor for endocytosis. Glycobiology 13 339-349.

Received 25 September 2009

First decision 19 October 2009

Revised manuscript received 13 April 2010

Accepted 22 April 2010 